\title{
Imposing Particular Identities: The Balkans as a Meeting Place of Ethnicities and Religions
}

\author{
MIRSAD KRIJEŠTORAC*
}

ABSTRACT Since Balkan ethnicities are primarily organized along locally-practiced religious lines, regional monotheistic religions are seen as the source of the conflicts there. However, even a brief historical examination shows different patterns, where the people of the region lived in long periods of peace and solidarity while practicing their separate religious traditions. Significantly, the conflicts occurred when the Balkan people followed non-religious political processes and ideas which originated outside of the region. Hence, this paper attempts to observe the extant representations of the Balkans, examine the brief history of the region to reveal patterns of amity and enmity, and bring forth a different historical-and possible future-reality.

\section{Balkans: Representations and Possibilities ${ }^{1}$}

$\mathrm{T}$ his paper will argue that monotheistic religions, which have coexisted for many centuries and, in fact, mark the most important axis of the human conception of history and individual self, are not the source of the exclusivism and particularism in the Balkans which so often led to war. Rather, the conflicts are the products of political processes that originated outside of the Balkans and which are anti-religious in essence. This becomes obvious when we consider that the Balkans, throughout their history, have experienced both periods of war and long periods of peace, characterized by cross-regional solidarity among the local peoples. Multiple religions have been present in the Balkans during all its modern history; therefore, something else must have disturbed the cross-regional solidarities and caused those conflicts. Thus, religious coexistence should be considered as a natural state of being, and viewed as such by all who are looking for solutions to the Balkan issues, with the peaceful and continuous complementary existence of the people in the Balkans as the final teleology. Since the opposite position has been well advertised and emphasized among the general public through various hegemonic

* Broward College, U.S. 2018, pp. 1-23 
The interplay of the Balkans being a part of Europe in terms of geography and whiteness, but with too little Northern calculus and too much Southern passion, determines largely when and what is going to be seen in the Balkans and what is not mechanisms for the production of representations, for us to argue otherwise is a tall order, but we have to consider the alternative to the current perspective of conflict and antagonism among different religions and ethnicities in the Balkans and elsewhere. ${ }^{2}$ This paper is just a step in the different direction, as we keep in mind that the geopolitical production of representations of regions and peoples are long-term processes $^{3}$ and, as such, should be important considerations for international relations inquiry. ${ }^{4}$ Our optimistic approach to the problem at stake is not unique. Another similarly aspiring approach to inquiry was suggested by Lijphart when he noted regarding democracy that, "if politicians and political scientists are convinced that democracy cannot work in the plural societies, they will not even try to introduce it or make it work." 5 So the optimism in the quest for the 'conflict solution' in the Balkans will not only be an underlying part of the logic of this paper, but should also be a part of the method of proceeding in the quest of achieving lasting harmony in the region. ${ }^{6}$

In our quest, we have to observe two issues: first, the geo-cultural context of the Balkans and the normative determination of the term 'Balkanization'; and second, the negative perception of religion in reference to the peace process, and with it the implications of such a view vis-à-vis ethnicity in the Balkans. ${ }^{7}$ This paper will employ a historical approach and will first address the intra-European regional representations and then the Balkans' religious and ethnic elements and their history of amity and enmity. In conclusion, this paper will offer an alternative position which argues for a serious and unbiased examination of the various political processes based on the different Northern European ideas of particularism as a source of 'vision and division', and a consideration and emphasis of religious universalism as a way forward in the Balkans.

\section{The Balkans as a Close Territory with Distant Peoples}

The Balkans is a well-known region of the world and most of the political constructions associated with it carry particularly heavyweight for the countries located there. The region was the subject of a Carnegie Endowment report originally published in 1914 and reprinted in 1996, which castigated the region, stating that, the "Balkan civilization was inferior and backward. Com- 
pared to the civilized world, its people had not yet 'obtained the stability of character found in older civilizations' nor the 'synthesis of moral and social forces embodied in laws and institutions giving stability of character, forming public sentiment, and making for security."' These heavy words should make us wonder how far the region and its people could move forward with these sorts of prejudices and representations circulating about it. ${ }^{9}$

Although the Balkan region is also designated as Southeastern Europe, in geopolitical language it is often alluded to as a region of instability and war and, for this reason, its 'Europeanness' is not emphasized; the Balkans are rather seen by Northern Europeans as the "other within," 10 or as Europe's internal Orient. This terminology denotes social and cultural distance primarily from the peoples of the Balkans, and less so from the territory itself. Europe's two-sided orientation toward the Balkans can be seen in the fact that the regional countries Romania and Bulgaria were readily accepted into the 'northern project' of the European Union as territories, while people of those countries still have a number of restrictions about traveling or remaining in most of the Northern European countries. Similar duplicitous European attitudes toward the region are also observed by Gerolymatos who noted, "It's called the Balkans when it's at war and Southeastern Europe when it's enjoying a period of peace." 1 So the interplay of the Balkans being a part of Europe in terms of geography and whiteness, ${ }^{12}$ but with too little Northern calculus and too much Southern passion, determines largely when and what is going to be seen in the Balkans and what is not. All of that, not because of some intellectual interest in such a culturally rich region, but mainly because "its messes might become ours," as H. Charles Woods noted a long time ago. ${ }^{13}$

The Balkans owes a lot to the Ottomans - most prominently their name- which is of Turkish origin, and signifies a mountain with bare cliffs. The name or adjective 'Balkans' was not much used until the 1880s. ${ }^{14}$ It replaced the ancient Greek name for the region, "Peninsula of Haemus."15 The connection with ancient Greece and the Balkans as the birthplace of Europe is often forgotten or lost among many other designations of the region. Cioroianu reminds us that "Europe is a creation of the Balkans... let's remember that Socrates, Plato, and Aristotle were Balkan and it was they who created Europe as a vision of world, philosophy, and wisdom. To the extent that it got Balkanized, Europe became Europe." 16 Those who produce a socially known reality ${ }^{17}$ do not point to such representations of the Balkans because any process of signification "produces truth rather than simply recording it." 18 Remembering the Balkan origins of Europe as well as the region's continuous and distinct ethnic and religious diversity, could bring forth some uncomfortable questions such as why the rest of Europe lacks such diversity. Obviously, the Northern European myths of their own origin involve more forgetting ${ }^{19}$ and alleviating perceived deficiencies in those myths than remembering. ${ }^{20}$ 


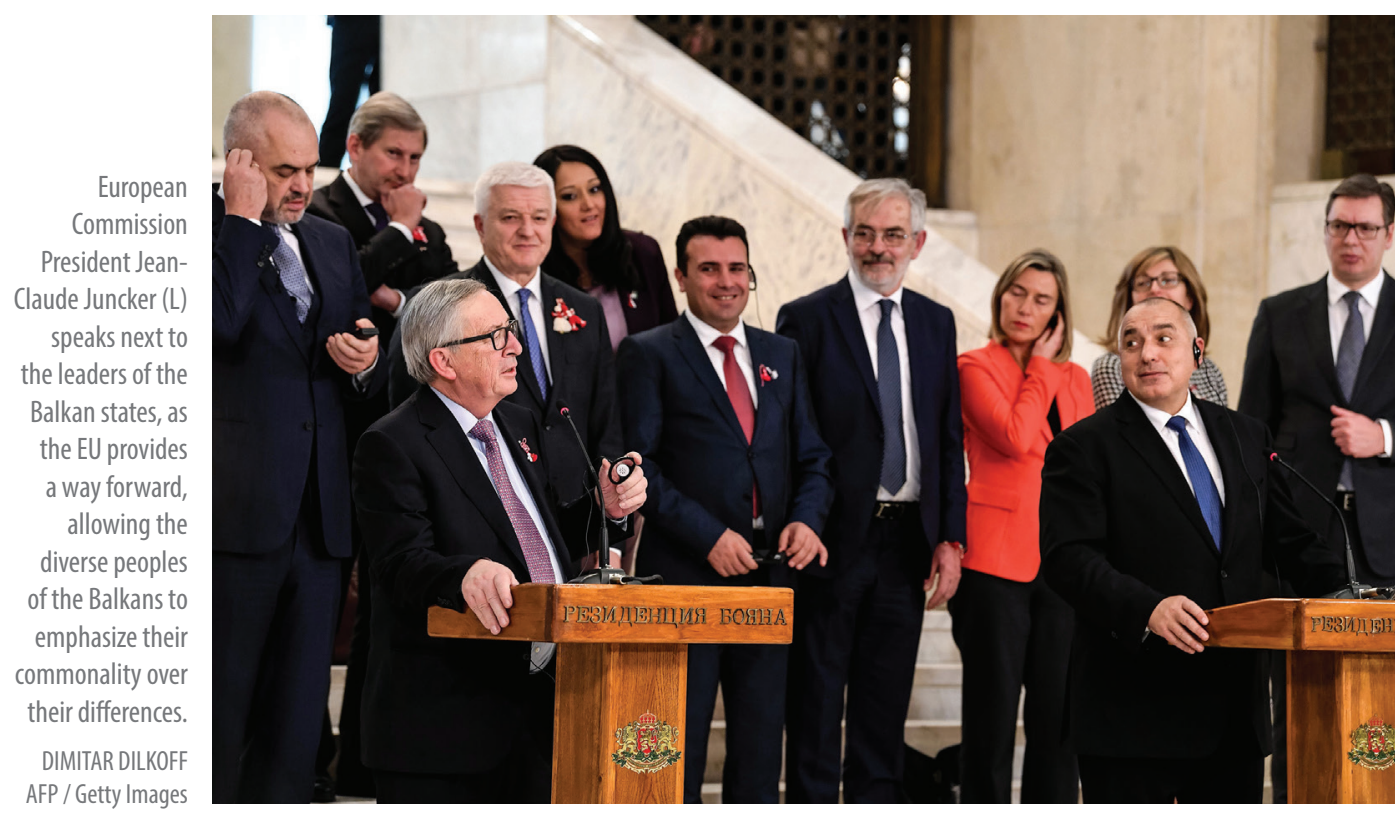

The relations between Northern Europe and the Balkans fit common worldwide north-south patterns, in which the representation of the "South has been discursively represented by policymakers, scholars, journalists and others in the North." ${ }^{21}$ We will note just some of the implications of those representations to show that the role for the Balkans is preset, and how the region is expected to fit in. ${ }^{22}$ As Slavoj Žižek noted in an interview, the people of the Balkans "are not caught up into their own dreams, but into European dreams of the Balkans."

The Southern European region is sometimes referred to as the Balkan Peninsula, but that geographical orientation does not completely coincide with a geopolitical reference. Geographically, the peninsula is widely regarded as a European region which bridges Europe with the Middle East and Asia; it is delimited by the Adriatic Sea in the west, the Black Sea in the east, the Aegean and Mediterranean Seas in the south, and the Alpine-Carpathian mountain folds with the Danube, Sava and Krupa rivers serving as the physical boundaries in the north. The countries of the region now are Albania, Bosnia and Herzegovina, Bulgaria, Greece, Kosovo, Macedonia, and Montenegro. However, the countries that are considered part of the geopolitical region also include states that are largely situated north of those rivers, such as Slovenia, Croatia and Serbia, as well as Romania and Moldova, which are located mostly past the eastern slopes of the Balkan Mountains. Sometimes geopolitical representations of the Balkans also include Turkey, though not when it is shrewdly categorized as a non-European. Many of these states, such as Slovenia and Roma- 
nia, shy away from being referred to as Balkan countries, but the regional pull often keeps them within the region's imagined boundaries.

It seems that the Balkans is one of those regions which is more than a spatial unit; rather, it is an entity interlinked with cultural, linguistic, economic, and political ties among various agents who come and go. ${ }^{24}$ Katzenstein notes that geographic designations in general often are not '"real,' 'natural', or 'essential.' They are socially constructed and politically contested and thus open to change." 25 Therefore, we can see the possibility for different productions of representations of the region, which then can set very different goals and expectations for their peoples and countries.

The main reasons some countries wish to escape the Balkan designation involve the widely accepted impression of regional instability and the perpetuated notion that the peoples of the Balkans belong to war-prone nations ${ }^{26}$ that resort to particularism and fighting more often than other European regions. As we saw, this perception figures into the EU's policies towards the citizens of the Balkan countries that had already become member states such as Bulgaria and Romania, or the different treatment of Greece's financial difficulties in comparison with northern European countries with the same problems. In fact, Orientalists even invented the term 'Balkanization, ${ }^{27}$ which became part of the global discourse to describe the division of a state into smaller states that are hostile towards each other. As with many other global perceptions and terms that are not sufficiently contested and are rather accepted as fact, this is an example of a Northern European invention that is difficult to dismantle. Since Europe is now in the midst of a new era seeking to remove many of divisions among its peoples and regions, it is important to recall that negative notions of the Balkans are a product of European ideas of particularism through the projects of nationalism and nation-states. ${ }^{28}$ These projects were encouraged (sometimes even forced upon the peoples in the Balkans) by other Europeans for both their own political agendas and the desire to project and multiply their own images elsewhere. ${ }^{29}$

Despite the influence of those essentially Northern European ideas, the blame for the Balkan carnage was usually placed solely upon the Balkans' religiously defined ethnic mosaic. ${ }^{30}$ Such suggestions imply that the multiplicity of re- 


\section{Despite all of those attempts by different outsiders to dominate the entire Balkans, however, the region still remains divided between the different geopolitical and military interest zones}

ligions among the peoples of the territory is inherently unnatural and detrimental for stability. ${ }^{31}$ In such preposterous constructions, 'secular' Europeans would emphasize the uncompromising nature of religion and the rigidity of religious boundaries. ${ }^{32}$ Those positions then create expectations that local actors should do whatever they can to simplify realities on the ground, so that diplomatic envoys can make sense of it. ${ }^{33}$ However, presenting these realities "as natural ... has disastrous consequences." ${ }^{34}$ When those simplified realities are projected on the ground under the watchful eye of European soldiers, as they were in Srebrenica and elsewhere, things are eventually done to stop the ethnic cleansings primarily because, for Northern Europeans, the Balkans are still seen "as part of 'us' and therefore [it is] impossible to let it descend into barbarism and cruelty to the degree which the West can accept in Africa" ${ }^{\prime 35}$ or the Middle East. No doubt, local actors themselves committed all the atrocities to each other and that should never be overlooked; however, the international countenance for the local carnage should be kept in mind as well.

\section{History}

Ever since the dawn of the Ottomans, the religions of the Balkan people have been seen as the building blocks of region's nation states, and have been (mis) used by outsiders and insiders for various local nationalism projects. ${ }^{36}$ More importantly for intra-European relations, because of those same locally practiced religions, the Balkan peoples are seen through the prism of otherness by the rest of Europe. This othering is mainly due to the fact that the dominant religions in the region are Christian Orthodoxy and Islam, with cultural heritages rooted in 'other' histories, namely those of the southern empires, Byzantine and Ottoman. The two states with predominant Catholic population, Slovenia and Croatia, accidentally or not, are also the states that sometimes manage to escape from the Balkan designations. Most notably, Slovenia quickly became a non-Balkan country after residing in the Balkans for a good part of the $20^{\text {th }}$ century when it was part of the former Yugoslavia.

\section{The Balkans as a Religious Frontier}

Since religions play such a central role in most of the visualizations about the Balkans, we should briefly consider local religions and how they -as essentially universalist worldviews- strangely morphed to become the most important ethnic and national boundary markers and source for particularism among the 
Balkan peoples. Local people's national identities should be seen as a dependent variable, which forms as the result of political processes: first as cross-regional cooperative identities as the result of the spread of religious ideas, then as narrow, particular, and so-called 'national identities' as the product of nationalism, and then as ambiguous identities (opened and closed at the same time) as the result of communist globalist ideology, and finally as exclusive, particular identities which came as the outcome of revitalized nationalism. ${ }^{37}$

By looking at the history one more time, we might be able to shed light on some of the less emphasized aspects of religions in the Balkans, and produce representations which will allow us to see the people of the region differently. We should keep in mind that seeing is a mental act and that a person can possibly see something only after correctly perceiving it, thus knowing and remembering it. ${ }^{38}$ In a current hegemony, however, knowledge about the Balkan's religious and cultural harmony is not being produced and such a situation makes perceptions skewed. As noted by Fasheh, "hegemony substitutes one kind of knowledge for another in the context of a power relationship. Power, in this sense, is almost defined by what is excluded." ${ }^{39}$

The Balkans' contemporary religious regional spatiality and particularism began with Diocletian's 285 A.D. decision to separate the Roman Empire into two parts. That separation also split the Balkans into two parts; one that turns bureaucratically and culturally northwest to Rome and later Catholicism, and the other which looked southeast to Constantinople, which eventually became the center of Orthodox Christianity before it was overrun by the Ottomans. Banac notes that the Balkans were the frontier zone even before the confessional split of the Roman empire, ${ }^{40}$ with different language zones of Latin and Greek running across the region. However, the stronger regional divide occurred after the full bureaucratic and confessional split in the fourth century, following the death of Theodosius I who was the last Emperor of a unified Rome, but with his throne in Byzantine's Constantinople. That regional divide culminated in the 1054 Great Schism between the two large Churches over the Eastern outlook on humanity's ability to perfect itself and the Western doctrine of original sin, and the different approach to Papal supremacy. ${ }^{41}$ The Great Schism gave "added sharpens to [all] future disputes." ${ }^{22}$ With the rise of the Ottomans, the region finally encountered the monotheism of Ghazi Islam, which many of the region's peoples embraced.

As mentioned earlier, the eastern part of the Empire was eventually overrun by the Ottomans, but before the Ottomans, the vast riches to the east provided the impetus for the conquest and pillage of Constantinople by Western European knights in the culmination of the Fourth Crusade in 1204. Along with their lasting economic consequences, the crusades also set the stage for a lot of 'religious' hatred among the two Christian groups globally. Not surprisingly, 


\section{The intra-Christian canonical wars over the souls and hearts of the people in the Balkans were eventually interrupted by the Ottoman conquest of the region and the subsequent introduction of Islam}

this hatred was primarily expressed in the regions where the two groups met head-on, such as in the Balkans, where the strategy of "divide and conquer" was often utilized by invaders to help them rule the region. There were numerous invaders in the Balkans, from ancient Romans, to Charlemagne's Franks, the Ottomans, Napoleon, the Russians, the Austro-Hungarians, Italians, Germans twice, the Soviets, and the Americans. In their wake, they left animosity and local divisions. Since there were so many invaders, it is evident that there was something valuable in the Balkans. Despite all of these attempts by different outsiders to dominate the entire Balkans, however, the region still remains divided between the different geopolitical and military interest zones, so we can expect that the region's exclusivism and particularism will continuously be encouraged in the future as well.

Another consequence of the split of the Roman Empire was that the territory of the Balkans became the periphery and the frontier for both empires. ${ }^{43}$ The designation of a territory as "frontier" usually means it is a place for "natural" expansions of powerful people and civilizations. Additionally, it often also means a place which needs to be tamed and "civilized," and that is a much uglier aspect of a regions' designation as a frontier.

Perhaps its distance from the center made the region susceptible very early on to the development of its own unique expressions of both Catholic and Orthodox Christianity. This was the place where one of the early European Christian heresies, that of the Bogumils and its cross regional variations like Bosnian Christians emerged. ${ }^{44}$ Interestingly, these religious developments are not only cross-ethnic and cross-national, but also cross-regional as well, showing an interesting level of cooperation and solidarity among different linguistic and ethnic groups in the Balkans and elsewhere very early on. Some authors, like Vasilev, even established the Balkan Bogumil's late $10^{\text {th }}$ century influence on later religious developments in Northern Europe which eventually led to the reformation. ${ }^{45}$ Whatever the case, one thing is undisputed: region-specific popular manifestations of religions were initially not well received by either church, and were subject to attempts to crush them "with the fire and sword" to use words of Pope John Paul II. ${ }^{46}$ Both Churches eventually took a different attitude and co-opted local manifestations in order to preserve the loyalty of local peoples and their Churches and to preserve their own canonical 
During the Second Balkan War the national liberation struggle which was advertised as religious rebellion was eventually replaced by a full-fledged, anti-religious nationalism that took the struggle to its desired end man Empire, many Muslims were prosecuted in the name of nationalism, and their numbers subsided. ${ }^{53}$ During the reign of the Ottomans, "customs evolved to offer security and insurance across the religious divide [and] young men of different families, and even different religions swore loyalty to each other." ${ }^{54}$

Whatever the case was then, now Muslims are an important part of the Balkan religious tapestry, most significantly in Albania, where they comprise 70 percent of the population; ${ }^{55} 47$ percent in Bosnia and Herzegovina (BiH); Bulgaria with about 16 percent; ${ }^{56}$ Kosovo over 95 percent; Macedonia arguably over 37 percent $^{57}$ while certainly as the country's second largest religion; ${ }^{58}$ Montenegro 17 percent; ${ }^{59}$ and less so in Serbia 3.2 percent; ${ }^{60}$ Greece about 1.5 percent, ${ }^{61}$ and Romania about 0.2 percent. ${ }^{62}$ Both of the recent wars of former Yugoslavia and the forceful expulsion of Muslims from $\mathrm{BiH}$, and recent movements of migrants from the Middle East and Asia, caused the number of Muslims to grow in Croatia to 1.3 percent, ${ }^{63}$ Slovenia 2.4 percent, ${ }^{64}$ and less than 1 percent in Hungary. ${ }^{65}$

The regional presence of Islam made some important contributions in terms of the revitalization of the universalist goals of monotheism, and the creation of new cross-regional solidarities among Muslims, and among Christians. ${ }^{66}$ In fact, Mazower notes that the Ottomans in effect unified the Balkans for the first time in centuries," and provided the possibility for such solidarities. Due to the previously mentioned Christian schisms and the Ottoman religious-based millet system, regional ethnicities emerged and catalyzed around religious orientations after the influence from North European ideas of nationalism and its particularisms. ${ }^{67}$ There was no room for the cross-regional and cross-religious solidarities among those who abandoned the old and accepted the new religion. However, those new local religious groups which could no longer rely on the old societal relations gained a new notion of theological solidarity among Muslims in general through religious conception of the Muslim ummah. In that way, the idea of religious universalism (of both Christians and Muslims since they feed off each other's ideas) remained alive among locals. All the Muslims in the world, including those in the Balkans feel a very strong sense of belonging to the same world faith community, ummah, as an entity beyond ethnicity and geography and, "the only viable form of voluntary grouping worthy of humanity." ${ }^{8}$ As an open society, the Muslim ummah is not restricted to Muslims only. Rather, one becomes a member by "confession of faith, or the covenant of peace." 69 
Such notions of a universal human association through faith are reinforced throughout Islamic teaching and all Muslims universally receive it. Faruqi presents it well when he describes that "even though host and guest may communicate with sign language, the brotherhood they share can make them marry into each other's family and act politically as well as juridically in the host's country or community." 70

\section{The End of the Religious World and the Beginning of the Nation State}

In addition to the Ottomans' religious ethnic policies and the millet system of governance, built on a long history of inter-religious coexistence and cooperation, ${ }^{71}$ the Ottomans managed to capture the hearts and minds of locals by honoring rights over private property, and a very clear tax system, with special regard and exemptions for the weak and poor regardless of their religion. Yet they did emphasize intra-religious solidarity as well. ${ }^{72}$ The strong intra-Muslim solidarity in turn eventually supported the Christian cross-regional solidarity. Regional Christian solidarity was used by outsiders like Russia to foment local outbursts of nationalism such as the Greek uprisings and the subsequent First Balkan War when the Ottomans were first pushed out of the Balkans. ${ }^{73}$ In the words of Fleming, the Greek Revolution "was at the popular level widely regarded as a fight for Christian freedom from the 'joke' of Islam"74 and as such was supported not only by neighboring Christians but wider Europe, particularly Britain, the homeland of Lord Byron, who was one of the most important figures of the revolution. The Greek War of Independence was by and large instigated by the educated elites who came from outside of Greece, whether they were Greeks or not. Inside of Greece, those better educated outsiders mobilized autochthon Greeks to fight and die along the most emotional elements of identity and religion; for them, liberation from the Ottomans was "the triumph of Christian good over Muslim tyranny." ${ }^{\prime 5}$ Fleming finds that large numbers of outsiders caused further emphasis on the local version of Orthodox Christianity as a real marker of Greekness and local origin. ${ }^{76}$ In such a way religion was solidified to be the primary marker not only of ethnicity, but of the maximalist expansion of the turf under control in the $19^{\text {th }}$ century. ${ }^{77}$ The lines between the religion and territorial expansionism in the Balkans have remained blurred ever since, as have the universalist messages of Christian monotheism. ${ }^{78}$

Despite those local uprisings, McCarthy notes that, "the Ottoman Empire did not constrict or collapse from internal revolution," ${ }^{2}$ and then goes on to elaborate on the role of Russia and Northern Europe in the Empire's demise. Fleming attests that the main factor was the "external pressure to bring [local frictions] to the level of violence." ${ }^{\prime 0}$ The path of conflict and exclusivism could not be stopped at that point, and after the defeat of the Ottomans, local Christian groups turned against each other in what later became known as the Second Balkan War, during which some of the previous gains of independence were reversed. The fog of those two wars made astonishing numbers of peo- 


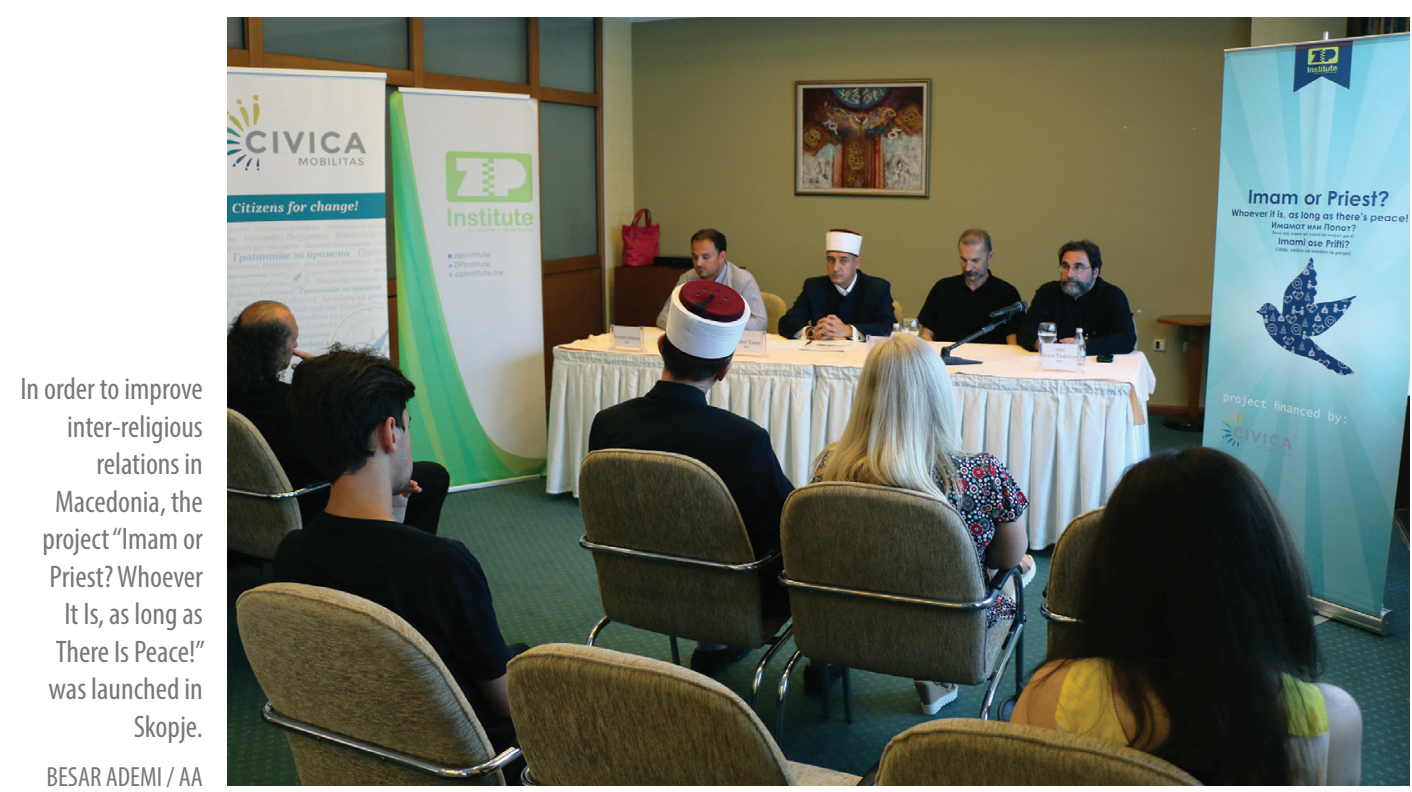

ple disappear. McCarthy established that a quarter of the Balkan Ottoman-era Muslims and other non-Muslims perished. ${ }^{81}$ But this antagonism was not only set along the Christian-Muslim line, "the Turks are fleeing before the Christians, the Bulgarians before Greeks and the Turks, the Greeks and Turks before Bulgarians, the Albanians before Serbians." ${ }^{2}$ As Fleming notes, "the sons of Isaac, and the sons of Ishmael... as on every occasion during the Greek Revolution, met with a common fate." ${ }^{33}$ Özkan quotes the famous writer Leon Trotsky, who was sent as young journalist to report from the Balkans about 'the Balkan Wars of liberation,' and who reported, 'the Bulgarian/Serbian rebels began their work the moment the sky grew dark. They broke into Turkish and Albanian homes and did the same thing, time and again: stole and slaughtered." ${ }^{84}$ Soon after these anti-Muslim outbursts, with the same fury Serbs, Bulgarians, Macedonians, and Greeks went after each other during the Second Balkan War despite the shared Orthodox Christianity among them. ${ }^{85}$ Obviously, religion was neither the motive, nor the cause of the bloodbath; rather it was the desire to pillage. What we could note, however, is that the national liberation struggle which was advertised as religious rebellion was eventually replaced by a full-fledged, anti-religious nationalism that took the struggle to its desired end. Therefore, in the case of the Balkan wars, we could see yet again that secular nationalism was able to trump and overtake religion in a war of national liberation. The Balkan case once more shows that secular nationalism as an "ideology of order" 86 prevailed over religion in the struggle for national liberation. Secular nationalism in the Balkans, driven by the European Great Powers, has since prevailed over religion when it comes to the formation and 
building of modern nation-states in the region. ${ }^{87}$

Such local expressions of particularism manifested through nationalisms and in turn solidified exclusive notions of national identity for most of the local groups; the dismal spiral of the modern Balkan wars was structured around those ideas. All that came as a result was a change of paradigm: from the Ottoman paradigm of cultural heterogeneity and religious tolerance, to the Northern European nation-state paradigm that was based on the Westphalian Peace Treaty principle of cuius regio, eius religio when the final subjugation of religion by the forces of particularism in Europe gained significant ground. ${ }^{88}$ Despite numerous representations of the Ottoman's Balkan rule as a tumultuous affair, more and more researchers like Greene ${ }^{89}$ show that the history of interactions among peoples of the Balkans with Ottoman rulers was not always marked by conflict and warfare, but instead was more often characterized by free trade, commerce, and the mutual growth of various communities.

Unresolved issues created in part by the Second Balkan War led the region and Europe into World War I, and several decades later into an even more deadly WWII. Such nationalism-induced inclination towards fixed, exclusive identities made all the regional countries, without exception, to amass very well-organized and structured domestic fascist forces which Hitler-led Germans installed into power locally. ${ }^{90}$

The spiral of conflict in the Balkans was then again interrupted by a new European universalistic ideology first formulated by Karl Marx and best known by its universalist slogan of "workers of the world unite." The most effective native resistance to the Germans and local manifestations of class-based fascism was spearheaded by homegrown Communists who cooperated among themselves in their struggle and spread their ideology across the region. ${ }^{91}$ They often did so by embracing all local religions and ethnicities, which often aided each other, ${ }^{92}$ initially insisting on malleable identities among them..$^{93}$ As a result, at the end of the war they emerged as leaders throughout the region. Only Greece and Turkey narrowly escaped Communist rule by employing extreme measures of military rule.

Communist rule, however, did bring about longed-for peace in the region; the main reason for its appeal lay in the initial inclusive, salient identity it offered, 
The supra-national and cross-regional project of the EU provides a new way forward and allows the diverse peoples of the Balkans to emphasize their commonness and strengthen their solidarity in spite of their ethnic and religious differences and the possibility of a new socialist-constructed, classless, inclusive identity. Local communists, however, could not effectively resolve their universalist ideals with local ethnic realities. The initial, inclusive approach was replaced with the titular, ethnic group dominance preferred by previous regimes. ${ }^{94}$ In the Slavic-speaking lands of Bulgaria and Yugoslavia, the Slavic ethnic group and their cultural themes became dominant. The Bulgarian communist government, for example, continued the policies of the Christianization (sic) of the Bulgarian Pomak Muslim population. ${ }^{95}$ In Yugoslavia such Slavic preferences were signaled by the adoption of the musical theme of the Pan-Slavic Polish anthem for its own national anthem, with lyrics modified to include parts of previous national songs. Furthermore, the official Serbo-Croatian language was named after the dominant Slavic-speaking Stokavian group, which alienated other ethnic groups, such as Macedonians, Magyars and Albanians. Things got even more complicated after Stalin's "top-down" Cominform orientation, and the 1948 resolutions which ostracized Tito's Yugoslavia's "bottom up," popular front approach to local manifestations of communist party political activity in the post-WWII era. ${ }^{96}$ The resolution caused serious tensions between the regional countries of Yugoslavia, Bulgaria and Albania. Interestingly, until then, the Yugoslav-led effort to unite those three countries in a Balkan union was almost plausible, but such a potentially independent powerful constellation could not take hold due to innumerable ideological differences, not only between local actors, but also among outside powers that feared such a potential union. ${ }^{97}$

Although the Communist split caused some regional instability, they managed to preserve the peace for the whole second part of the $20^{\text {th }}$ century. Eventually, the paradoxes between Marxist theory and local communist-led parties' praxis caused the collapse of the system, ${ }^{98}$ and a West-encouraged nationalism stepped in one more time to sew destruction and mow down the lives of local people.

Once again, the universalist messages of monotheistic, Christian religions were bent and (mis)represented through that same prism of particularism, and the modern ( sic) synthesis of church and nation, to justify local carnages. The religion of Christianity was used by some Balkan nationalists to justify notions such as 'ethnic cleansing,' "whereby God became in effect not a universal God, but the God of a particular nation," 99 despite the fact that such policies are essentially antithetical to any monotheistic religion, including the Christian 
universalist principle of human brotherhood and care for human salvation. More recently, similarly strange exclusivist manifestations against autochthonous Muslims emerged in Bulgaria, but they were mainly rejected by both local Christians and Muslims. ${ }^{100}$

\section{The Way Forward}

What now? The hope for new peace is not lost. The supra-national and cross-regional project of the $\mathrm{EU}^{101}$ provides a new way forward and allows the diverse peoples of the Balkans to emphasize their commonness and strengthen their solidarity in spite of their ethnic and religious differences. The EU has a somewhat ambivalent approach to religion vs. Church, where the position of the former is unspecified while the position of the later is specified. The European (and international) state structure is mainly organized upon the 1648 Westphalian arrangement, "after which the church and state were to share power." 102 The position and power of the Church therefore was not nixed by the state, only limited to some undefined station. Therefore, although often presented as such, the Westphalian structure did not bring a strict separation of Church, religion and state. The same notion is represented by Article 52 on the status of churches and non-confessional organizations under the terms of the now-revised EU treaty (read as 'the proposed future constitution') of a super-modern creation of Kantian ideas which regulates that "the Union shall maintain an open, transparent and regular dialogue with these churches and organizations." Religion, apart from Church, is not specifically mentioned and the EU still does not have a clear approach towards it. This opens up the space to re-conceptualize religion as a possible ally in building the true EU supra-national inclusive identities that religion (apart from Church) would have no problem with, since it also essentially advocates all-inclusive human solidarity above and beyond the old concept of a national state. ${ }^{103}$ This paper is not trying to "question the authority of the authority," it is just urging those who shape public reality to acknowledge the authoritarian voice of religion that speaks to millions of willing listeners every day, and conceive a different manifestation of it as possible and normal!

That is why all those who are concerned with the productions of representations of and about the Balkans should emphasize those possibilities. For that project, the universalist messages of local monotheistic religions could serve well. Perhaps they should be included into a locally developed compilation of "a constitutional religion" in a manner suggested by Gellner. ${ }^{104}$ Religious frameworks are often flexible enough to allow the emergence of new interpretations of the basic concepts to fit and support the new particular circumstances. ${ }^{105}$ As Istvan Deak wrote in a New York Times opinion piece, "Archduke Otto Hapsburg, the last pretender to the crowns of Austria and Hungary, warned that economic 
It is past time to turn the table of Balkan representation, "to reclaim and transform what has been made invisible," and to display the region's religious and ethnic diversity as an inherent quality, and a building block of cooperation and progress cooperation alone would not satisfy the peoples of Europe and that European unification could not succeed unless it was imbued with an abstract principle." 106 The universalist appeal of monotheistic religions is a good fit for that. So instead of looking at religions as a source of conflict, the time has come for all those concerned to look at the religions of the Balkans as a potential source of peace and cooperation, precisely because of the continuous

coexistence of different ethnicities and their religions over the centuries. It is also the time to rethink why the Balkans are perceived as a place of hatred and intolerance while the continuous presence and coexistence of various ethnicities and religions for many centuries, uncommon in other parts of Europe, testifies to a different reality. As we remember and emphasize that fact, we could notice that local religions, as one of the main markers of ethnicity in the Balkans, played an important part in that history of commonness as well, far more so than other European ideas and movements. Exploring regional history in such a way is not intended "to reveal truths that have been obscured, but rather to examine how certain representations underlie the production of knowledge and identities and how these representations make various courses of actions possible" as Doty well observed. ${ }^{107}$ It is past time to turn the table of Balkan representation, "to reclaim and transform what has been made invisible," ${ }^{108}$ and to display the region's religious and ethnic diversity as an inherent quality, and a building block of cooperation and progress.

\section{Endnotes}

1. I must thank the journal's reviewers for the excellent comments and suggestions regarding the earlier version of this paper. I also thank my dear colleague, Bilal Çıplak, for his initial comments about the topic, as well as Stephanie Brenenson and Katherine Taylor for their patience and efforts to improve this paper.

2. Both ethnicity and nation are seen here as unfixed categories of social and political life. See note 30 .

3. For example, in 1895, in his conversations with the novelist H. G. Wells, American President Theodore Roosevelt spoke about the "queer little ape like figures" of [Balkan] Morlocs. For more see, Larry Wolff, "The Rise and Fall of 'Morlacchismo:' South Slavic Identity in the Mountains of Dalmatia," in Norman M. Naimark and Holly Case (eds.), Yugoslavia and Its Historians: Understanding the Balkan Wars of the 1990s, (Stanford: Stanford University Press, 2003), pp. 48-49.

4. For Doty, representations "take place within political and social circumstances in which other kinds of differences are implicitly presumed. Because the question of representation has been excluded, the historical constructions and consequences have not been considered legitimate realms of inquiry." Roxanne L. Doty, Imperial Encounters: The Politics of Representation in North-South Relations, (Minneapolis: University of Minnesota Press, 1996), p. 4. 
5. Arend Lijphart, Democracy in Plural Society, (New Haven: Yale University Press, 1977), p. 3.

6. After all, Eckstein notes that the orientations of actors towards possible outcomes are learned through external socializers directed by "teachers," and this is to be a reminder to them. Harry Eckstein, "A Culturalist Theory of Political Change," The American Political Science Review, Vol. 82, No. 3 (1988), pp. 789-804.

7. While ethnicity in the Balkans is chiefly defined by religion, such an approach sometimes creates paradoxes. For example, Bosnian Muslim nationality during the time of Yugoslavia was in a constant state of duality, where religion was accepted as the very basis of their groupness, and at the same time, that religious basis was disapproved of in its essential form by the state structure. The EU could potentially run into the same problem with many religious groups demanding to be recognized for their uniqueness, both as a form and as practice.

8. "1914 Report," Carnegie Endowment, pp. 267, 271, cited in Lene Hansen, "Past as Preface: Civilizational Politics and the 'Third' Balkan War," Journal of Peace Research, Vol. 37, No. 3 (2000), pp. 345-362.

9. Even the meaning of the name Balkan was "stretched to refer to the entire region" because of the erroneous assumption that it is a mountain range extending across the peninsula instead of a mountain range with a mountain passage. That is how it became "Balkans," instead of the original, singular "Balkan." See, Mark Mazower, The Balkans: A Short History, (New York: Modern Library, 2002).

10. Vasiliki P. Neofotistos, "The Balkans' Other Within: Imaginings of the West in the Republic of Macedonia," History and Anthropology, Vol. 19, No. 1 (2008), pp. 17-36.

11. Andre Gerolymatos, The Balkan Wars, (New York: Basic Books, 2003), p. 14.

12. Also noted by Fleming: "It seems that what is so perplexing about the Balkans is the interplay between Balkan peoples' visible similarity to Western Europeans (their whiteness and their geography) and their perceived barbaric behavior that causes the sense of uneasiness with that similarity." See, Katherine Elizabeth Fleming, "Orientalism, the Balkans, and Balkan Historiography," The American Historical Review, Vol. 105, No. 4 (2000), pp. 1218-1233.

13. Fleming, “Orientalism, the Balkans, and Balkan Historiography," pp. 1218-1233.

14. See, Mazower, The Balkans.

15. Maria Todorova, Imagining the Balkans, (New York: Oxford University Press, 2002).

16. Adrian M. Cioroianu, "The Impossible Escape: Romanians and the Balkans," in I. Bijelic Dusan and Obrad Savic (eds.), Balkan as Metaphor: Between Globalization and Fragmentation, (Cambridge: MIT Press, 2002), p. 226.

17. Berger and Luckmann established long ago that, "only a very limited group of people in any society engages in theorizing, in the business of 'ideas' and the constructions of Weltanschauungen." Peter $\mathrm{L}$. Berger and Thomas Luckmann, The Social Construction of Reality: A Treatise in the Sociology of Knowledge, (Garden City: Doubleday, 1996), p. 15.

18. Husserol, as mentioned by Michael J. Shapiro, Language and Political Understanding: The Politics of Discursive Practices, (New Haven: Yale University Press, 1981), p. 56.

19. Ernest Gellner, Nationalism, (New York: New York University Press, 1997).

20. Eugene Kamenka, Nationalism: The Nature and Evolution of an Idea, (New York: St. Martin's Press, 1976).

21. Doty, Imperial Encounters, p. 2.

22. Hajdarpsic describes how that approach to the Balkans has been dominant since the19th century. See, Edin Hajdarpasic, Whose Bosnia: Nationalism and Political Institutions in the Balkans, 1840-1914, (New York: Cornell University Press, 2015).

23. "Euronews Talks with Slavoj Žižek" Euronews Youtube, retrieved on June 1, 2017, from http://youtu. be/EzM8tqjmCU8.

24. For more see, Vesna Goldsworthy, "Invention and In(ter)vention: The Rhetoric of Balkanization," in I. Bijelic Dusan and Obrad Savic (eds.), Balkan as Metaphor: Between Globalization and Fragmentation, pp. 25-38. 
25. Peter J. Katzenstein, "Introduction: Asian Regionalism in Comparative Perspective," in Peter J. Katzenstein and Shiraishi Takashi (eds.), Network Power: Japan and Asia, (New York: Cornell University Press, 1997), pp. 1-44.

26. All of those nations, like most others in the world, are multi-ethnic and multi-religious international entities and by their attempts to "escape the Balkans" they are also trying to escape that attribute of their existence. For more on the multi-ethnic reality of nations, see chapter four in Walker Connor, Ethnonationalism: The Quest for Understanding, (Princeton: Princeton University Press, 1998).

27. The term "Balkanization" was invented to highlight the negative attributes of heterogeneous state realities in the region and elsewhere. The ambiguity of this term is evidenced by the Britannica definition: "division of a multinational state into smaller ethnically homogeneous entities. The term also is used to refer to ethnic conflict within multiethnic states. It was coined at the end of World War I to describe the ethnic and political fragmentation that followed the breakup of the Ottoman Empire, particularly in the Balkans." See, Robert W. Pringle, "Balkanization," Britannica, retrieved from http://www. britannica.com/EBchecked/topic/50323/Balkanization. It is obvious from this definition that regional multi-ethnic ethos is taken as a self-evident reason for political fragmentation, despite the reality that all those different people lived together in peace far longer than in war. See, Frank P. Harvey, "Primordialism, Evolutionary Theory and Ethnic Violence in the Balkans: Opportunities and Constraints for Theory and Policy," Canadian Journal of Political Science/ Revue Canadienne de Science Politique, Vol. 33, No. 1 (2000), pp. 37-65.

28. In agreement with Vincent, particularism is seen as an essence of nationalism. For more see, Andrew Vincent, Nationalism and Particularity, (Cambridge: Cambridge University Press, 2000).

29. Anderson notes that once the concept of a modern nation was "invented" by Northern Europeans, and then imposed upon the rest of the world as the exclusive source of legitimacy, it became something that was globally desired. See, Benedict Anderson, Imagined Communities: Reflections on the Origin and Spread of Nationalism, (New York: Verso, 1983), p. 86.

30. Ethnicity is seen as Barth describes it in his seminal work on ethnic groups. Barth places emphasis on ethnicity as a group which "identifies itself, and is identifiable by others as constituting a category distinguishable from other categories of the same order" (p. 11). However, in defining the phenomenon, Barth is explaining that those categories do not form and exist in isolation from each other, rather that they readily borrow cultural components and shape each other's boundaries through both symbiotic and competing relationships. For Barth and his co-authors, again, the difference among ethnic groups does not entail conflict; nay, sameness or similarity might more readily be the reason for conflict than difference. For more see, Fredrik Barth (ed.), Ethnic Groups and Boundaries: The Social Organization of Cultural Difference, (Long Grove: Waveland Press, Inc., 1998). Furthermore, an ethnic group is a flexible social form which could be shaped to mean different things in different situations; therefore ethnicity does not have to be a reason for conflict. This argument is supported by the fact that an ethnic group is often larger than a nation (e.g. Slavs, Arabs, Germans, etc.) and this again highlights that ethnicity could assume different traits in different situations. The same goes for a nation which also often contains multiple ethnic groups, languages and religions. Therefore, Connor correctly explains that the difference between ethnicity and nation therefore lies only in the consciences of the members of each social form, where nation is exclusively self-defined (members are self-aware of its existence); while ethnicity could also be other-defined (group could be defined just in terms of not being someone else). See, Connor, Ethnonationalism.

31. However, empirical observations showed that there is no consistent relationship between ethnic diversity and the likelihood of a civil war, and that different ethnicities cooperate nearly all the time! The culprit is rather a weak (nation) state unable to provide basic services to its population. See, David D. Laitin, Nations, States, and Violence, (New York: Oxford University Press, 2007), pp. 9-22.

32. While, in fact, other evidence and common humanistic orientation could point to a different conclusion. For evidence of religiosity not being a source of intolerance see, Robert M. Kunovich and Randy Hodson, "Conflict, Religious Identity, and Ethnic Intolerance in Croatia," Social Forces, Vol. 78, No. 2 (1999), pp. 643-668. For a focused discussion on the common humanistic legacy of religions and possible conclusion see, Richard Falk, "A Worldwide Religious Resurgence in an Era of Globalization," in Pavlos Hatzopoulos and Fabio Petito (eds.), Religion in International Relations: The Return from Exile, (New York: Palgrave Macmillan, 2003), pp. 181-209. 
33. The so-called Carrington-Cutileiro, Vance-Owen, and Owen-Stoltenberg color-coded plans prejudiced ethnically cleansed units of Bosnia and Herzegovina, and were eventually codified in the Dayton peace accord which was then advertised as the only viable solution. For more see, Galen Ted Carpenter, "Jackboot Nation Building: The West Brings 'Democracy' to Bosnia," Mediterranean Quarterly, Vol. 11, No. 2 (2000), pp. 1-22.

34. V. P. Gagnon, Jr., The Myth of Ethnic War: Serbia and Croatia in the 1990s, (New York: Cornell University Press, 2006), p. 25.

35. Barry Buzan and Ole Wæver, Regions and Powers: The Structure of International Security, (Cambridge: Cambridge University Press, 2007), p. 387.

36. A historian of the Balkans, Peter Sugar in 1997 observed that "the remarkable Balkan territorial persistence of the Ottomans throughout the century can in large part "be explained by the jealousy among the great powers that worked against each other always giving the Ottomans a 'friend' in the foe of their enemies."' As mentioned in Katherine Elizabeth Fleming, "Introduction" in Katherine Elizabeth Fleming (ed.), The Muslim Bonaparte: Diplomacy and Orientalism in Ali Pasha's Greece, (Princeton: Princeton University Press, 1999), p. 12.

37. See, Mirsad Kriještorac, "Nationalism as a Process for Making the Desired Identity Salient: Bosnian Muslims Become Bosniaks," Ph.D. thesis, Florida International University, 2016, retrieved from http:// digitalcommons.fiu.edu/etd/3004/.

38. For Huxley, seeing is predicated upon correct perception, therefore, it is also a mental act that depends on accumulated experience (memory) and general and particular knowledge of a person trying to see. People of the Balkans have the experience of living together, but the interpretation of that experience is skewed by the likes of all those previously mentioned. Therefore, such knowledge cannot support the observer in seeing normalcy in the Balkan's religious differences. See, Aldous Huxley, The Art of Seeing, (Berkeley: Creative Arts Book Co., 1982).

39. Munir Fasheh, "Community Education: To Reclaim and Transform What Has Been Made Invisible," Harvard Educational Review, Vol. 60, No. 1 (1990), p. 24.

40. Ivo Banac, The National Question in Yugoslavia, (New York: Cornell University Press, 1984), p. 59.

41. Robert Browning, The Byzantine Empire, (Washington: The Catholic University of America Press, 1992), pp. 120-121.

42. Jonathan Phillips, "The Fourth Crusade and the Sack of Constantinople: Jonathan Phillips Sees One of the Most Notorious Events in European History as a Typical 'Clash of Cultures,"' History Today, Vol. 54, No. 5 (2004), pp. 21-28.

43. Subsequently, the border region between Croatia and Bosnia, which was also more or less the border between the two empires, is still called Krajina (frontier).

44. For more on the Bogumils see the excellent work by Dmitri Obolensky, The Bogumils: A Study in Balkan Neo-Manichaeism, (Cambridge: Cambridge University Press, 2004). For more on Bosnian Christians see, John V. A. Fine, The Bosnian Church: A New Interpretation. A Study of the Bosnian Church and its Place in State and Society from the $13^{\text {th }}$ to the $15^{\text {th }}$ Centuries, (New York: Columbia University Press, 1975).

45. Georgi Vasilev, Heresy and the English Reformation: Bogomil-Cathar Influence on Wycliffe, Langland, Tyndale and Milton, (Jefferson: McFarland \& Company, Inc., 2008).

46. Vasilev, Heresy and the English Reformation, p. 101.

47. Noel Malcolm, Bosnia: A Short History, (New York: New York University Press, 1994), p. 41.

48. Banac, The National Question in Yugoslavia, p. 62.

49. Born as Rastko, Saint Sava (1174-1236) lived and rose into prominence at the onset of the Ottoman conquest of the Balkans and Serbia, which most likely permanently influenced the development of particularization within Orthodox Christianity (see, Emmert 1981). At the time, Saint Sava was an embodiment of the strong ties of the religious and political powers in the Serbian states of Hum and Raška (the territory of present-day Sandžak). Coming from the regional ruling family of Nemanjić, Sava pushed for the establishment of an autonomous Orthodox Christian Church, initially against the wishes of the central Byzantine Bishop. However, Sava was not only a priest; he was also a diplomat and briefly even 
the ruler of the state of Hum. He authored the document Zakonopravilo (Rules and Laws), which Serbs now refer to as the oldest Serbian Constitution. After he established the independent church, he was canonized and venerated by the same church and its followers. His teaching significantly influenced the local practice and understanding of Serbian Orthodoxy. Papo (2015) notes that for the Serbs, "Jesus is saintly, but not divine [and Jesus is] reduced to a mere saint. Even if holding the position of the chief of all the saints, Jesus does not seem to be the focus of Serbian folk religion and peasant imagination" (p. 30). Rather, Saint Sava is. See, Eliezer Papo, "The Last Supper and 'Knezeva Vecera:' Parallels and Their Resonances in Traditional Christian and Serbian Folk Culture," Slavic and East European Journal, Vol. 59, No. 1 (2015), pp. 23-46. For more see, Thomas Emmert, "Kosovo - Development and Impact of a National Epic," in Ivo Banac, John Ackerman and Roman Szporluk (eds.), Nation and Ideology: Essays in Honor of Wayne S. Vucinich, (Boulder: Columbia University Press 1981), pp. 61-86.

50. Ivan Lopasic, "The Muslims of Bosnia," in Gerd Nonneman, Tim Ninblock and Bogdan Szajkowski (eds.), Muslim Communities in the New Europe, (Berkshire: New York Press, 1996), pp. 99-115.

51. Jacek Duda, "Islamic Community in Serbia," in Katarzyna Gorak-Sosnowska (ed.), Muslims in Poland and Eastern Europe: Widening the European Discourse on Islam, (Warsaw: University of Warsaw, 2011), pp. 327-336.

52. The spread of new religion was slow and gradual, and there is no evidence of the forceful conversion of locals to Islam. See, Fine, The Bosnian Church. Filipović notes that Islam was initially accepted by the younger generation as can be observed in Turkish tefters from that period which often note a Christian father and one or two Muslim sons. See, Nedim Filipovic, Islamizacija u Bosni i Hercegovini [Islamization of Bosnia], (Tesanj, B-H: Centar za Kulturu i Obrazovanje, 2005), p. 103. The same can be observed in the Ottoman court records, as Amila Buturovic notes in her work, Carved in Stone, Etched in Memory: Death, Tombstones and Commemoration in Bosnian Islam Since c. 1500, (Burlington: Ashgate, 2015), p. 6.

53. May F. Myuhtar, Identity, Nationalism, and Cultural Heritage Under Siege: Five Narratives of Pomak Heritage - from Forced Renaming to Weddings, (Leiden: Brill, 2014).

54. Mazower, The Balkans, p. 62. Also see, Petar Vlahović, Brodarevo i njegova okolina. (Etnološka rasprava) [Brodarevo and its Surroundings. (Ethnological Discussion)], (Belgrade: University of Belgrade, 1968).

55. Elira Çela, "Albanian Muslims, Human Rights, and Relations with the Islamic World," in Gerd Nonneman, Tim Niblock and Bogdan Szajkowski (eds.), Muslim Communities in the New Europe, (Berkshire: New York Press, 1997), pp. 139-153.

56. Ivan Ilchev and Duncan Perry, "The Muslims of Bulgaria," in Nonneman, Niblock and Szajkowski (eds.), Muslim Communities in the New Europe, pp. 115-139.

57. Mirsad Krijestorac, "Democratic Transitions in Multiethnic States: Case Comparison of Macedonia and Montenegro," Alternatives: Turkish Journal of International Relations, Vol. 14, No. 2 (2015), pp. 37-69.

58. Mirjana Najcevska, Emilija Simoska, and Natalia Gaber, "Muslims, State and Society in the Republic of Macedonia: The View from Within," in Nonneman, Niblock and Szajkowski, Muslim Communities in the New Europe, pp. 75-99.

59. Erin K. Jenne and Florian Bieber, "Situational Nationalism: Nation-building in the Balkans, Subversive Institutions and the Montenegrin Paradox" Ethnopolitics, Vol. 13, No. 5 (2014), pp. 431-460.

60. Ahmet Alibašić, "Serbia's Muslim Population," in Jørgen . Nielsen, Samim Akgönül, Ahmet Alibašić, Maréchal Brigit and Christian Moe (eds.), Yearbook of Muslims in Europe, (Leiden: Brill, 2011), pp. 458-467.

61. Gerd Nonneman, "Muslim Communities in the New Europe: Themes and Puzzles," in Nonneman, Niblock and Szajkowski, Muslim Communities in the New Europe, pp. 1-25.

62. Daniela Stoica, "New Romanian Muslims: Converted Women Sharing Knowledge in Online and Offline Communities," in Gorak-Sosnowska (ed.), Muslims in Poland and Eastern Europe, pp. 266-286.

63. Houssain Kettani, "2010 World Muslim Population," (2010), retrieved from https://upload.wikimedia. org/wikipedia/commons/b/b8/World_Muslim_Population_2010.pdf.

64. Veronika Bajt, "The Muslim Other in Slovenia: Intersections of Religious and Ethnic Minority," in Gorak-Sosnowska (ed.), Islam, Muslims in Poland and Eastern Europe, pp. 286-307. 
65. Irina Moldokova, "Formation of New Muslim Communities in New Member States: The Case of Hungary," in Gorak- Sosnowska (ed.), Muslims in Poland and Eastern Europe, pp. 207-222. Although such a small number for the population of Muslims in Hungary is disputed, and some claim the number is higher, it should be noted that Hungarians historically had good relations with Muslims and Islam and only recently, the far-right voices became aggressively anti-Muslim. See, Zoltan Pall and Omar Sayfo, "Why an Anti-Islam Campaign Has Taken Root in Hungary, a Country with Few Muslims," V4 Revue, (September 14, 2016), retrieved October 6, 2016, from http://visegradrevue.eu/ why-an-anti-islam-campaign-has-taken-root-in-hungary-a-country-with-few-muslims/\#.

66. For example, Çelik notes that "the Orthodox Church became an Ottoman institution and the Patriarch was a high-level Ottoman official with the rank of vizier." See, Nihat Çelik, "The Black Sea and the Balkans under Ottoman Rule," Karadeniz Araştırmaları, Vol. 6, No. 24 (2010), pp. 1-27.

67. "Ethnicity was as much the consequence as a cause of the unrests [since] local peasants were concerned more to regain stability in their lives than to die for nationalism." See, Mazower, The Balkans, p. 99.

68. Ismail Faruqi, "Islam: Movement for World Order," International Institute of Islamic Thought, retrieved June 29, 2012, from http://www.iiit.org/Portals/0/faruqi/lslam-movementforworldorder.pdf, p. 9.

69. Faruqi, "Islam: Movement for World Order."

70. Faruqi, "Islam: Movement for World Order."

71. See, Çelik, "The Black Sea and the Balkans under Ottoman Rule," pp. 1-27.

72. Çelik also notes that the first thing the Ottomans did when they took over an area was to create various pious foundations (waqfs), with caravanserais to provide security in those areas, serve travelers and stimulate trade and commerce, and imarets (public kitchens). Çelik, "The Black Sea and the Balkans under Ottoman Rule," pp.13-14.

73. Mazower, The Balkans, p. 91.

74. Katherine Elizabeth Fleming, Greece - A Jewish History, (Princeton: Princeton University Press 2008), p. 17.

75. Fleming, Greece - A Jewish History, p. 30. The late Ottoman reign was indeed often bloody as they desperately tried to stop their inevitable demise. See, Mazower, The Balkans, p. 94.

76. Victor Roudometof, "Greek Orthodoxy, Territoriality, and Globality: Religious Responses and Institutional Disputes," Sociology of Religion, Vol. 69, No. 1 (2008), pp. 67-91.

77. In case of Serbs outside of Serbia, in the lands where similar Shtokavian dialects of the Slavic language are spoken, and where teachers, priests, and bureaucrats were historically supplied by Serbia, Christian Orthodoxy means Serbianism in the ethnic sense as well. This is an interesting twist of the norm that in Serbia works the other way. There, Serbianism means the Saint Sava version of Christian Orthodoxy. The same relations locally work between Catholicism and the Croats. Both examples show how religion (and ethnicity) was trumped by nationalism projects to serve some very temporal goals. In her revealing essay, Balić notes that the similar question of who exactly was considered a Serb in Bosnia was not clear even during WWII. See, Emily Greble Balić, "When Croatia Needs Serbs: Nationalism and Genocide in Sarajevo, 1941-1942," Slavic Review, Vol. 68, No. 1 (2009), pp. 116-138. See especially, pp. 123-128.

78. For more see, Miklos Tomka, "Secularization and Nationalism," in John Coleman and Miklos Tomka (ed.), Religion and Nationalism, (London, SCM Press, 1995), pp. 22-33.

79. Justin McCarthy, Death and Exile: The Ethnic Cleansing of Ottoman Muslims, 1821-1922, (Princeton: The Darwin Press Inc., 1995), p. 13.

80. Fleming, Greece - A Jewish History, p. 34.

81. McCarthy, Death and Exile, pp. 161-164.

82. Mazower, The Balkans, p. 117.

83. Fleming, Greece - A Jewish History, p. 17.

84. Behlül Özkan, From the Abode of Islam to the Turkish Vatan: The Making of a National Homeland in Turkey, (New Haven: Yale University Press, 2012). 
85. See for example Banac, The National Question in Yugoslavia, pp. 318-320.

86. In his earlier work, Juergensmeyer proposes to observe both secular nationalism and religion as "ideologies of order" which struggle with each other over whose order is better for a nation. For more see, Mark Juergensmeyer, The New Cold War? Religious Nationalism Confronts the Secular State, (Berkley: University of California Press, 1993), pp. 26-39.

87. An anonymous Bulgarian observer stated long ago, "[again and again] quarrels between Balkan countries can be created and/or fostered, as well as prevented or settled by energetic action of the Great Powers." Anonymous, "Bulgarian Views on a Durable Peace," The Slavonic and East European Review, Vol. 23, No. 62 (1945), pp. 63-68.

88. As Smith notes in a chapter about genocide, "after the Treaty, the appeal of national sovereignty becomes too strong to resist and it was not a coincidence that Max Weber then defined the monopoly of legitimate violence in their own territories as the core principle of state sovereignty" (p. 373). However, the very idea of sovereignty is increasingly becoming a source of instability since the implications of this demarcation do not satisfy the national and other interests of all citizens of a state. For more see, David Norman Smith, "The Rhetoric and Reality of 'Mass Destruction': How Genocide Became an International Social Problem," in George Ritzer (ed.), Handbook of Social Problems: A Comparative International Perspective, (Thousand Oaks: Sage Publications, 2004), pp. 368-388.

89. Molly Greene, "Trading Identities: The Sixteenth Century Greek Moment," in Adnan A. Husain and Katherine Elizabeth Fleming (eds.), A Faithful Sea: The Religious Cultures of the Mediterranean, 1200-1700, (Oxford: Oneworld Publications, 2007), pp. 121-149.

90. For more see, Marko Attila Hoare, The Bosnian Muslims in the Second World War: A History, (New York: Oxford University Press, 2013).

91. See, Geoffrey Swain, "The Cominform: Tito's International?," The Historical Journal, Vol. 35, No. 3 (1992), pp. 641-663.

92. The story of the Sarajevo Hagadah is an example of it. Or even more, is the example of Albanian Muslims protecting Jews who manage to escape from northern Europe to Albania. The multiethnic, multi-religious, Southern European, predominantly Muslim, Albania is the only state in Europe where the Jewish population grew during the Axis occupation. See, Bernd Jurgen Fischer, Albania at War, 19391945, (Indiana: C. Hurst \& Co. Publishers, 1999), p. 187.

93. An example was the Yugoslav Communist all-embracing policy of "brotherhood and oneness (unity)" among people.

94. For Yugoslavia, Banac describes such unitaristic orientation as continuation of the platform of the Serbian Social-Democratic Party. See, Banac, The National Question in Yugoslavia, pp. 333-338.

95. Myuhtar, Identity, Nationalism, and Cultural Heritage under Siege, p. 108.

96. Swain, The Cominform: Tito's International?

97. For how the topic is addressed over time see, Christine Galitzi, "The Balkan Federation," The Annals of the American Academy of Political and Social Science, Vol. 168, (1933), pp. 178-182; or Adam B. Ulam, "The Background of the Soviet-Yugoslav Dispute," The Review of Politics, Vol. 13, No. 1 (1951), pp. 39-63; and David A. Andelman, "China's Balkan Strategy," International Security, Vol. 4, No. 3 (1980), pp. 60-79.

98. For more see, Roy Macridis, "Stalinism and the Meaning of Titoism," World Politics, Vol. 4, No. 2 (1952), pp. 219-238.

99. Roudometof, "Greek Orthodoxy, Territoriality, and Globality: Religious Responses and Institutional Disputes," pp. 67-91.

100. A Bulgarian mufti commented on it as follows: "This hatred is new to us," said Hadji. "It's the first time we have seen such nationalism and seen such hatred towards others. Most Muslims are rural. The problem is not in rural areas, it is in towns and in cities. Nationalism has more power [there] than in the villages," he said. "In the city, people don't know each other so well. In the village, Muslims and Christians live and pray together. Nationalism has no way to separate them." Quoted in Anna Zacharias, "Attacks on Bulgarian Mosques: 'This Hatred Is New to Us"' The National, (October 21, 2011), re- 
trieved May 20, 2015, from http://www.thenational.ae/featured-content/channel-page/news/attackson-bulgarian-mosques-this-hatred-is-new-to-us.

101. As a call for the fullest European integrations, Denis de Rougemont, called for a "Europe of the regions" not for Europe of the nations, recognizing that insisting on integration of the nations will probably not yield good results since nations are not very tolerant forms for the new type of modernity which provides room for new identities that cross exclusive state and national lines. Let us remember that the EU started as a cross regional project and that ever since then, the primary vehicle of functionalist-driven integrations are regions, despite the fact that the primary political agents are states. Regions are considered here as both sub-state and supra-state units. For a persuasive invitation to re-consider regions and new modernity see, Celia Applegate "A Europe of Regions: Reflections on the Historiography of Sub-National Places in Modern Times," The American Historical Review, Vol. 104, No. 4 (1999), pp. 1157-1182.

102. Paulleta Otis, "Religion and War in the Twenty-first Century," in Robert A. Seiple and Denis Hover (eds.), Religion and Security: The New Nexus in International Relations, (Lanham: Rowman \& Littlefield, 2004), pp. 11-25.

103. Charles Taylor also observed that the modern states' grand narrative of dominance through secularism will be more and more challenged and in the world of "post-secular" Europe we are at the beginning of a new age of religious searching" and it is indeed very useful to recount those previous successful experiences from regions like the Balkans where multiple and different religions remind to shape and coexist with each other. For more see, Charles Taylor, A Secular Age, (Cambridge: The Belknap Press of Harvard University, 2007).

104. Ernest Gellner, Postmodernism, Reason and Religion, (London: Routledge, 1992) p. 91.

105. See, Andrew M. Greeley, Religion, a Secular Theory, (New York: Free Press, 1982), pp. 97-98.

106. Istvan Deak, "Where's Charlemagne When We Need Him?," The New York Times, (June 30, 2012), retrieved June 30, 2015, from http://www.nytimes.com/2012/07/01/opinion/sunday/wheres-charlemagne-when-we-need-him.html?_r=2.

107. Doty, Imperial Encounters, p. 5.

108. Fasheh, Community Education, pp. 19-35. 